\title{
Treatment of lactating sows with clofibrate as a synthetic agonist of PPARa does not influence milk fat content and gains of litters
}

Denise K Gessner ${ }^{1}$, Birthe Gröne, Susann Rosenbaum, Erika Most ${ }^{1}$, Sonja Hillen², Sabrina Becker², Georg Erhardt ${ }^{3}$, Gerald Reiner ${ }^{2}$ and Klaus Eder ${ }^{1 *}$

\begin{abstract}
Background: In rats, it has been observed that treatment with activators of peroxisome proliferator-activated receptor a (PPARa) disturbs metabolic adaptations during lactation, which in turn lead to a reduction of milk fat content and gains of litters during the suckling period. It has not yet been investigated whether agonists of PPARa are impairing milk production of lactating sows in a similar manner as in rats. Therefore, the present study aimed to investigate the effect of treatment with clofibrate, a strong synthetic agonist of PPARa, on milk composition and litter gains in lactating sows.
\end{abstract}

Results: Twenty lactating sows received either a basal diet (control group) or the same diet with supplementation of $2 \mathrm{~g}$ of clofibrate per $\mathrm{kg}$ of diet (clofibrate group). In the clofibrate group, mRNA concentrations of various PPARa target genes involved in fatty acid utilization in liver and skeletal muscle were moderately up-regulated. Fat and energy content of the milk and gains of litters during the suckling period were not different between the control group and the clofibrate group.

Conclusion: It is shown that treatment with clofibrate induces only a moderate up-regulation of PPARa target genes in liver and muscle of lactating sows and in turn might have limited effect on whole body fatty acid utilization. This may be the reason why clofibrate treatment did not influence milk fat content and gains of litters during the suckling period. Thus, the present study indicates that activation of PPARa induced either by native agonists such as dietary polyunsaturated fatty acids or a by negative energy balance might be largely uncritical in lactating sows with respect to milk production and litter gains in lactating sows.

\section{Background}

Lactation is a physiological state which in most animal species is associated with a strong increase in energy and nutrient requirement for milk production. This demand is usually met by marked increase in feed intake and by utilization of body's energy stores. In some animal species such as rats or mice, additionally metabolic adaptations occur during lactation which aim to conserve energy for milk production [1-3]. Down-regulation of proteins involved in fatty acid uptake and oxidation in liver and skeletal muscle and a decreased thermogenesis contribute to these energy sparing effects [3-6]. We have

\footnotetext{
* Correspondence: klaus.eder@ernaehrung.uni-giessen.de

${ }^{1}$ Institute of Animal Nutrition and Nutritional Physiology, Justus-Liebig-University Giessen, Heinrich-Buff-Ring 26-32, 35392 Giessen, Germany

Full list of author information is available at the end of the article
}

observed that these effects in lactating rodents are mediated by a suppression of peroxisome proliferator-activated receptor $\alpha$ (PPAR $\alpha)$, a transcription factor which controls the expression of many genes involved in lipid catabolism $[7,8]$. In lactating rats, it has been moreover observed that an activation of PPAR $\alpha$ by feeding an oxidized fat causes a disturbance of those metabolic adaptations. It has been found that there was an increased uptake of fatty acids into the liver and an increased oxidation of fatty acids in the lactating rats fed the oxidized fat, which in turn led to a reduced availability of fatty acids for milk production, resulting in a reduced milk triacylglycerol (TAG) concentration and reduced growth rates of the suckling pups [9].

In lactating sows, milk production is important for the post-natal growth of their litters. However, in contrast to rodents, the role of PPAR $\alpha$ in lactating sows has not yet 
been determined. According to rodent studies, an activation of PPAR $\alpha$ during lactation could suppress milk fat synthesis due to a reduced availability of fatty acids as a result of an increased utilization of fatty acids by liver and muscle. The question whether activation of PPAR $\alpha$ could affect milk fat synthesis is of relevance as dietary components such as polyunsaturated fatty acids (PUFA) are able to activate PPAR $\alpha$ [10-12]. Moreover, it is known that a negative energy balance which is common in lactating sows causes an activation of PPAR $\alpha$ due to increased concentrations of NEFA in plasma released from adipose tissue [13-15]. Indeed, recently an activation of PPAR $\alpha$ in liver of lactating sows with a negative energy balance has been observed [16-18]. However, metabolic effects of activation of PPAR $\alpha$ in lactating sows have not been investigated so far. In order to investigate the hypothesis that activation of PPAR $\alpha$ could impair milk production, we performed an experiment with lactating sows which were fed a diet supplemented with clofibrate as a synthetic agonist of PPAR $\alpha$ and determined milk composition and gains of litters.

\section{Methods}

\section{Animals and diets}

Twenty second parity sows (Large White and German Landrace) were artificially inseminated and kept in single crates until day 21 of pregnancy. From day 21 to 110 of pregnancy, the sows were kept in groups in pens equipped with fully slatted floors, nipple drinkers and feeders with a temperature of $19 \pm 1^{\circ} \mathrm{C}$ with a $12: 12 \mathrm{~h}$ light-dark cycle and $60-80 \%$ relative humidity by means of an air conditioning system. On day 110 of pregnancy, they were housed individually in farrowing crates. After parturition, the sows were randomly assigned into two feeding groups of 10 animals each with an equalized litter size of 8 piglets per sow. Infrared heaters were used to provide a surrounding temperature of $35^{\circ} \mathrm{C}$ for newborn pigs. The duration of the suckling period was 21 days.

During lactation all sows were fed a nutritionally adequate basal diet consisting mainly of (in $\mathrm{g} / \mathrm{kg}$ diet): wheat (325), barley (400), soybean meal with $43 \%$ crude protein (190), a mixture of soybean oil and palm oil (50) $(1: 4, \mathrm{w} / \mathrm{w})$ and a mineral supplement (35) (Sauengold Lac, Sano-Moderne Tierernährung GmbH, Loiching, Germany). The basal diet contained 13.8 MJ metabolizable energy $(\mathrm{ME}) / \mathrm{kg}$; concentrations of crude nutrients were $(\mathrm{g} / \mathrm{kg}$ diet): Crude protein, 154; crude fat, 74; crude fiber, 45; crude ash, 43; starch, 395. Major fatty acids of the basal diet were ( $\mathrm{g} / 100 \mathrm{~g}$ of total fatty acids): Palmitic acid (16:0), 31.5; stearic acid (18:0), 3.9; oleic acid (18:1), 30.7; linoleic acid (18:2 n-6), 29.4; $\alpha$-linolenic acid (18:3 n-3) 2.0. The control group received the basal diet without any further supplement. The second group ("clofibrate group") received the basal diet supplemented with $2 \mathrm{~g}$ of clofibrate (Sigma-Aldrich, Schnelldorf, Germany) per kg of diet. At the day of parturition, the sows were given $3 \mathrm{~kg}$ of the diet. From day 2 of lactation to later lactation, the amount of diet administered was calculated in order to meet the energy requirement of the sows (assuming daily litter gains of $2 \mathrm{~kg}$ ) [19]. Water was given ad libitum by nipple drinkers. Feed intakes were recorded daily and body weights weekly. The energy balance of the sows during lactation was estimated as the difference of ME intake and total energy requirement for maintenance and energy requirement for milk production. It was assumed that milk production for $1 \mathrm{~kg}$ of litter gain is equivalent to an energy demand of 29.3 MJ ME [19]. The piglets were offered a creep feed (Bonni M-Forte, Sano-Moderne Tierernährung) from day 15 until weaning.

All experimental procedures were carried out in accordance with established guidelines for the care and handling of laboratory animals and were approved by the local Animal Welfare Authorities (Regierungspräsidium Giessen; permission no: GI 19/3-No. 29/2010).

\section{Sample collection}

On day 20 of lactation, blood from Vena jugularis was collected $3 \mathrm{~h}$ after feed intake into heparinized polyethylene tubes (Sarstedt, Nürnberg, Germany) and plasma was subsequently obtained by centrifugation of the blood $\left(1100 \times \mathrm{g}, 10 \mathrm{~min}, 4^{\circ} \mathrm{C}\right)$ and stored at $-20^{\circ} \mathrm{C}$. On day 20 , liver and muscle biopsy samples were taken percutaneously after anaesthesia by intramuscular injection of 2 mg azaperon (Stresnil, Janssen, Germany) per kg body mass, 20 mg ketamine (Ursotamin, Serumwerke Bernburg AG, Germany) per $\mathrm{kg}$ body mass and up to $2.4 \mathrm{mg}$ thiopental (Thiopental $0.5 \mathrm{~g}$, Inresa, Freiburg, Germany) per kg body mass as required for maintenance of anaesthesia. The pigs were placed in the left lateral recumbency and the surgical area was infiltrated with $1 \mathrm{~mL}$ of $2 \%$ lidocaine hydrochloride (BelaPharm, Vechta, Germany) for local anaesthesia. A percutaneous liver biopsy was performed with a $16 \mathrm{G} / 1.65 \mathrm{~mm}$ biopsy needle (length: $160 \mathrm{~mm}$ ) on a HistoCore ${ }^{\bullet}$ system (BIP Biomed. Instrumente \& Produkte GmbH, Türkenfeld, Germany) on expected anatomical location of the liver under constant ultrasound guidance. The intramuscular biopsy (M. longissimus dorsi) was performed with a spirotome (8 G, Medinvents, Hasselt, Belgium). After removal of the samples, the sites for biopsy were subsequently closed with synthetic absorbable surgical suture. For collection of milk samples, sows were given 20 I.U. oxytocin (CP-Pharma, Burgdorf, Germany) by intramuscular injection. $80-100 \mathrm{ml}$ of milk was expressed manually from all active teats of each sow. Liver and muscle samples were stored at $-80^{\circ} \mathrm{C}$ and milk samples were stored at $-20^{\circ} \mathrm{C}$ pending analysis. 


\section{Concentrations of nutrients in milk}

Measurements of protein and fat concentrations in the milk were performed by the official methods of Verband Deutscher Landwirtschaftlicher Untersuchungs- und Forschungsanstalten (VDLUFA) [20]. The concentration of lactose in the milk was determined using a commercial kit (cat. no. 10986119035, R-Biopharm, Darmstadt, Germany) according to the manufacturer's instructions. The gross energy content of the milk was calculated using the following gross energy values: fat $=39 \mathrm{~kJ} / \mathrm{g}$, protein $=24 \mathrm{~kJ} / \mathrm{g}$, lactose $=17 \mathrm{~kJ} / \mathrm{g}$. For analysis of the fatty acid composition of milk total lipids, lipids were extracted from the milk with a hexane:isopropanol (3:2, v/v) mixture [21]. Fatty acids were analyzed by capillary gas chromatography after converting fatty acids into their methyl esters by trimethyl sulfonium hydroxide [22]. Concentrations of retinol and $\alpha$-tocopherol in milk samples were determined by HPLC (L-7100, LaChrom, Merck-Hitachi, Darmstadt, Germany) using a modification of the method of Balz et al. [23]. Samples of $0.5 \mathrm{ml}$ of milk were mixed with $2 \mathrm{ml}$ of a $10 \mathrm{~g} / \mathrm{l}$ pyrogallol solution (in ethanol, absolute) and $300 \mu \mathrm{l}$ of a saturated sodium hydroxide solution. After flushing with nitrogen, this mixture was heated for $30 \mathrm{~min}$ at $70^{\circ} \mathrm{C}$ in closed glass tubes. Retinol and $\alpha$ tocopherol were then extracted by addition of $2 \mathrm{ml}$ of $\mathrm{n}$ hexane and $2 \mathrm{ml}$ of bidest. water. After centrifugation, an aliquot of the hexane phase was evaporated to dryness under nitrogen and re-dissolved in methanol containing $0.05 \%$ of butylated hydroxytoluene. Retinol and $\alpha$ tocopherol were separated isocratically by HPLC using a mixture of methanol and water $(96: 4, \mathrm{v} / \mathrm{v})$ as mobile phase and a LiChrosher 100 RP18 column $(5 \mu \mathrm{m}$ particle size, $125 \mathrm{~mm}$ length, $4.6 \mathrm{~mm}$ internal diameter, Merck, Darmstadt, Germany) and detected by fluorescence (Fluorescence Detector L-7480, LaChrom, Merck-Hitachi, Darmstadt, Germany; retinol: excitation wavelength, $325 \mathrm{~nm}$, emission wavelength, $475 \mathrm{~nm}$; $\alpha$-tocopherol: excitation wavelength, $295 \mathrm{~nm}$, emission wavelength, $325 \mathrm{~nm}$ ).

\section{Concentration of TAG and NEFA in plasma}

Plasma concentrations of TAG and NEFA were measured using enzymatic kits [Fluitest ${ }^{\circledR}$ TG, Cat. No. 5741, Analyticon ${ }^{\circledast}$ Biotechnologies AG, Lichtenfels, Germany; NEFA-HR (2), Code No. 436-91995, Wako Chemicals $\mathrm{GmbH}$, Neuss, Germany].

\section{RNA isolation and qPCR}

RNA isolation from frozen liver and muscle biopsies and quantitative real-time PCR (qPCR) analysis were performed as described recently in detail [24]. In brief, total RNA from frozen liver and muscle samples was isolated using Trizol ${ }^{\odot}$ Reagent (Invitrogen, Karlsruhe, Germany) according to the manufacturer's protocol and purified using the RNeasy Minikit (Qiagen, Hilden, Germany).
Concentration and purity of the RNA were estimated from the optical density at 260 and $280 \mathrm{~nm}$, respectively. The integrity of total RNA was verified using $1.2 \%$ agarose gel electrophoresis. cDNA was synthesized using $1.2 \mu \mathrm{g}$ of total RNA, $100 \mathrm{pmol}$ oligo $(\mathrm{dT})_{18}$ primer (Eurofins MWG Operon, Ebersberg, Germany), $1.25 \mu \mathrm{l}$ $10 \mathrm{mM}$ dNTP mix (GeneCraft, Lüdinghausen, Germany), $5 \mu \mathrm{l} 5 \mathrm{x}$ RT reaction buffer (Thermo Fisher Scientific, St. Leon-Rot, Deutschland), and 60 units MMuLV Reverse Transcriptase (Thermo Fisher Scientific) at $42^{\circ} \mathrm{C}$ for $60 \mathrm{~min}$ and a final inactivating step at $70^{\circ} \mathrm{C}$ for $10 \mathrm{~min}$ in a thermo cycler (Biometra, Göttingen, Germany). qPCR runs were performed with a Rotorgene 2000 system (Corbett Research, Mortlake, Australia) using KAPA SYBR FAST qPCR Universal Mastermix (Peqlab, Erlangen, Germany) and gene-specific primer pairs from Eurofins MWG Operon (Ebersberg, Germany). Ct-values of target and reference genes were obtained using Rotorgene Software 5.0. Determination of relative expression levels was calculated using GeNorm normalization factor including the three most stable out of six reference genes [25]. Gene-specific primer pairs were designed intron-spanning if possible using Primer3 and BLAST. Characteristics of primers used for $\mathrm{qPCR}$ analysis are shown in Table 1.

\section{Statistical analysis}

Statistical analysis was performed by student's t test using the Minitab Statistical Software Rel. 13.0 (Minitab, State College, PA, USA). Differences were considered statistically significant for $P<0.05$.

\section{Results}

Daily feed intake, body weights and energy balance of the lactating sows

The daily feed intake during the three weeks of lactation was not different between control sows and sows administered clofibrate (Table 2). Body weights of the sows at day 1 post partum and day 21 post partum and body weight losses of the sows from day 1 to day 21 were similar in both groups of sows (Table 2). The calculated energy balance of the sows from day 1 post partum to day 14 post partum, the time period in which piglets did not receive any additional feed, was also similar in both groups of sows (Table 2).

mRNA concentrations of PPARa target genes in tissues of the lactating sows

In overall, administration of clofibrate had only a moderate effect on the expression of the PPAR $\alpha$ target genes in liver and muscle of sows on day 20 of lactation (Table 3). In the liver, mRNA concentrations of only 2 out of the 7 PPAR $\alpha$ target genes considered (CPT1A and CYP4A24) were significantly up-regulated by administration of 
Table 1 Characteristics of gene specific primers used for qPCR

\begin{tabular}{|c|c|c|c|c|c|c|c|}
\hline \multirow[t]{2}{*}{ Gene } & Forward primer (from $5^{\prime}$ to $3^{\prime}$ ) & \multirow{2}{*}{$\begin{array}{l}\text { PCR product } \\
\text { size (bp) }\end{array}$} & \multirow[t]{2}{*}{ NCBI GenBank } & \multirow[t]{2}{*}{ Slope } & \multirow[t]{2}{*}{$\mathrm{R}^{2}$} & \multirow[t]{2}{*}{ Efficiency } & \multirow[t]{2}{*}{ M-value } \\
\hline & Reverse primer (from 5' to $3^{\prime}$ ) & & & & & & \\
\hline \multicolumn{8}{|c|}{ Reference genes } \\
\hline \multirow[t]{2}{*}{$A C T B$} & GACATCCGCAAGGACCTCTA & 205 & XM_003124280.3 & -3.76 & 1.000 & 0.84 & 0.034 \\
\hline & ACATCTGCTGGAAGGTGGAC & & & & & & \\
\hline \multirow[t]{2}{*}{ ATP5G1 } & CAGTCACCTTGAGCCGGGCGA & 94 & NM_001025218.2 & -3.43 & 0.999 & 0.99 & 0.033 \\
\hline & TAGCGCCCCGGTGGTTTGC & & & & & & \\
\hline \multirow[t]{2}{*}{ GSR } & AGCGCGATGCCTACGTGAGC & 175 & XM_003483635.2 & -3.43 & 0.997 & 0.96 & 0.038 \\
\hline & GGTACGCCGCCTGTGGCAAT & & & & & & \\
\hline \multirow[t]{2}{*}{ RPS9 } & GTCGCAAGACTTATGTGACC & 325 & XM_005664825.1 & -3.78 & 0.999 & 0.84 & 0.034 \\
\hline & AGCTTGAAGACCTGGGTCTG & & & & & & \\
\hline \multicolumn{8}{|c|}{ PPARa target genes } \\
\hline \multirow[t]{2}{*}{ ACOX1 } & CTCGCAGACCCAGATGAAAT & 218 & NM_001101028.1 & -3.53 & 0.999 & 0.92 & \\
\hline & TCCAAGCCTCGAAGATGAGT & & & & & & \\
\hline \multirow[t]{2}{*}{ CD36 } & TCCTCTGACATTTGCAGGTCAATCT & 107 & NM_001044622.1 & -3.59 & 0.999 & 0.90 & \\
\hline & GGAGATGCAAAAGCTGTGGATGG & & & & & & \\
\hline \multirow[t]{2}{*}{ CPT1A } & GCATTTGTCCCATCTITCGT & 198 & NM_001129805.1 & -3.46 & 0.999 & 0.95 & \\
\hline & GCACTGGTCCTTCTGGGATA & & & & & & \\
\hline \multirow[t]{2}{*}{ CPT1B } & CACACTGCAGCACCTCACA & 183 & NM_001007191.1 & -4.09 & 1.000 & 0.76 & \\
\hline & GTGAGGGCTGCCAGCTTाT & & & & & & \\
\hline \multirow[t]{2}{*}{ CYP4A24 } & GGTTTGCTCCTGTTGAATGG & 121 & NM_214424.1 & -3.34 & 1.000 & 0.99 & \\
\hline & GCATCACTTGGACAGACTTG & & & & & & \\
\hline \multirow[t]{2}{*}{ FABP1 } & ATCGTGCAGAATGGGAAGCA & 133 & NM_001004046.1 & -3.43 & 0.999 & 0.96 & \\
\hline & ACTGAACCACTGTCTTGACC & & & & & & \\
\hline \multirow[t]{2}{*}{ FABP3 } & CAACATGACCAAGCCTACCA & 227 & NM_001099931.1 & -3.36 & 1.000 & 0.98 & \\
\hline & CTAGTTCCCGAACAAGCGTT & & & & & & \\
\hline \multirow[t]{2}{*}{$L P L$} & TTCTCCCGACGACGCAGATTTT & 166 & NM_214286.1 & -3.36 & 0.988 & 0.98 & \\
\hline & TGCAATCACACGGATGGCTTCT & & & & & & \\
\hline \multirow[t]{2}{*}{ SLC27A1 } & GGTTCCAGCCTGTTGAATGT & 275 & NM_001083931.1 & -3.38 & 0.992 & 0.98 & \\
\hline & AACAAAACCTTGGTGCTTGG & & & & & & \\
\hline \multirow[t]{2}{*}{ UCP3 } & GCCACTTTGTCTCTGCCTTC & 219 & NM_214049.1 & -3.39 & 1.000 & 0.97 & \\
\hline & CAAACATCACCACGTTCCAG & & & & & & \\
\hline \multicolumn{8}{|c|}{ Genes of the ubiquitin proteasome system } \\
\hline \multirow[t]{2}{*}{ FBXO32 } & TCACAGCTCACATCCCTGAG & 167 & NM_001044588.1 & -3.30 & 0.994 & 1.01 & \\
\hline & GACTTGCCGACTCTCTGGAC & & & & & & \\
\hline \multirow[t]{2}{*}{ TRIM63 } & ATGGAGAACCTGGAGAAGCA & 219 & NM_001184756.1 & -3.62 & 0.998 & 0.89 & \\
\hline & ACGGTCCATGATCACCTCAT & & & & & & \\
\hline$U B B$ & GGTGGCTGCTAATTCTCCAG & 127 & NM_001105309.1 & -3.51 & 1.000 & 0.93 & \\
\hline & TITTGGACAGGTTCAGCTATTAC & & & & & & \\
\hline
\end{tabular}

Abbreviations: ACOX1 acyl-CoA oxidase, ACTB actin, beta, ATP5G1 ATP synthase, $\mathrm{H}+$ transporting, mitochondrial Fo complex, subunit $\mathrm{C1}$, CD36 fatty acid translocase, CPT1 carnitine-palmitoyl-transferase, CYP4A24 cytochrome P450 A24, FABP fatty acid binding protein, FBXO32 F-box protein 32, LPL lipoprotein lipase, GSR glutathione reductase, PPARa peroxisome proliferator- activated receptor a, RPS9 ribosomal protein S9, SLC27A1 solute carrier family 27 (fatty acid transporter), member 1, TRIM63 tripartite motif containing 63, E3 ubiquitin protein ligase, UBB ubiquitin B, UCP3 uncoupling protein 3.

clofibrate $(P<0.05$, Table 3$)$. The extent of upregulation for these genes, with the only exception of CPT1A was moderate. In muscle, there was a significant
$(P<0.05)$ up-regulation of 5 out of the 8 PPAR $\alpha$ target genes considered (ACO, CD36, CPT1B, CYP4A24, LPL). As in the liver, the extent of up-regulation of these 
Table 2 Daily feed intake, body weights and energy balance of lactating control sows and sows administered clofibrate

\begin{tabular}{llll}
\hline & Control & Clofibrate & $P$-value \\
\hline Daily feed intake (kg/d) & & & \\
Week 1 & $6.06 \pm 0.65$ & $5.47 \pm 0.75$ & 0.088 \\
Week 2 & $5.88 \pm 0.91$ & $6.26 \pm 0.63$ & 0.333 \\
Week 3 & $6.29 \pm 0.57$ & $6.28 \pm 0.97$ & 0.978 \\
Weeks 1-3 & $6.08 \pm 0.54$ & $6.00 \pm 0.67$ & 0.807 \\
Body weight (kg) & & & \\
Day 1 p.p. & $264 \pm 15.4$ & $263 \pm 18.3$ & 0.910 \\
$\quad$ Day 21 p.p. & $247 \pm 21.0$ & $242 \pm 27.9$ & 0.688 \\
Body weight loss (kg) & & & \\
Day 1 p.p. - day 21 p.p. & $16.9 \pm 9.14$ & $20.9 \pm 16.42$ & 0.550 \\
Energy balance (MJ ME/d), & & & \\
Day 1 p.p. - day 14 p.p. & $-4.91 \pm 13.25$ & $-9.24 \pm 8.88$ & 0.436 \\
\hline
\end{tabular}

Values are mean $\pm S D(n=10 /$ group $) ;$ p.p. $=$ post partum.

genes, being in the range between $43 \%$ and $68 \%$, however, was relatively moderate (Table 3 ).

\section{Concentrations of TAG and NEFA in plasma}

The concentrations of TAG and NEFA in plasma on day 20 of lactation were significantly lower in the clofibrate group than in the control group $(P<0.05$, Table 4$)$.

Table 3 Relative mRNA concentrations of PPARa target genes in liver and muscle of lactating control sows and sows administered clofibrate on day 20 of lactation

\begin{tabular}{llll}
\hline & Control & Clofibrate & $P$-value \\
\hline Liver & & & \\
ACOX1 & $1.00 \pm 0.61$ & $1.16 \pm 0.65$ & 0.577 \\
CD36 & $1.00 \pm 0.38$ & $0.91 \pm 0.39$ & 0.656 \\
CPT1A & $1.00 \pm 0.75$ & $3.86 \pm 1.77$ & 0.003 \\
CYP4A24 & $1.00 \pm 0.47$ & $1.66 \pm 0.57$ & 0.034 \\
FABP1 & $1.00 \pm 0.36$ & $1.32 \pm 0.42$ & 0.144 \\
LPL & $1.00 \pm 0.49$ & $1.48 \pm 0.48$ & 0.104 \\
SLC27A1 & $1.00 \pm 0.47$ & $0.96 \pm 0.14$ & 0.835 \\
MusCle & & & \\
ACO & $1.00 \pm 0.36$ & $1.62 \pm 0.38$ & 0.002 \\
CD36 & $1.00 \pm 0.16$ & $1.43 \pm 0.16$ & $<0.001$ \\
CPT1B & $1.00 \pm 0.37$ & $1.64 \pm 0.53$ & 0.001 \\
CYP4A24 & $1.00 \pm 0.38$ & $1.52 \pm 0.31$ & 0.012 \\
FABP3 & $1.00 \pm 0.24$ & $1.27 \pm 0.35$ & 0.094 \\
LPL & $1.00 \pm 0.51$ & $1.68 \pm 0.48$ & 0.010 \\
SLC27A1 & $1.00 \pm 0.10$ & $1.12 \pm 0.14$ & 0.101 \\
UCP3 & $1.00 \pm 0.32$ & $1.16 \pm 0.20$ & 0.296 \\
\hline
\end{tabular}

Values are mean $\pm S D(n=10 /$ group); Abbreviations: see Footnote of Table 1.
Table 4 Concentrations of TAG and NEFA in plasma of lactating control sows and sows administered clofibrate on day 20 of lactation

\begin{tabular}{llll}
\hline & Control & Clofibrate & P-value \\
\hline TAG $(\mathrm{mmol} / \mathrm{L})$ & $0.37 \pm 0.13$ & $0.23 \pm 0.09$ & 0.029 \\
NEFA $(\mu \mathrm{mol} / \mathrm{L})$ & $152 \pm 66$ & $64 \pm 18$ & 0.002 \\
\hline
\end{tabular}

Values are mean $\pm S D(n=10 /$ group).

Milk composition of the lactating sows and gains of litters Concentrations of fat, lactose and the calculated gross energy content of the milk on day 20 of lactation did not differ between control sows and sows administered clofibrate. However, the concentration of protein in the milk was higher in the clofibrate group than in the control group (Table 5). The fatty acid composition of milk total lipids was slightly different between the two groups of sows. In the milk of sows administered clofibrate, the proportion of palmitic acid (16:0) was slightly higher and proportions of linoleic acid (18:2 n-6) and $\alpha$-linoleic acid (18:3 n-3) were slightly lower than in milk of control sows (Table 5). Proportions of all the other fatty acids in milk total lipids were unchanged between the two groups of sows (Table 5). According to the differences in the proportions of palmitic acid, linoleic acid and $\alpha$ -

Table 5 Composition of milk of lactating control sows and sows administered clofibrate on day 20 of lactation

\begin{tabular}{|c|c|c|c|}
\hline & Control & Clofibrate & $P$-value \\
\hline \multicolumn{4}{|l|}{ Nutrients (\%) } \\
\hline Fat & $6.81 \pm 0.49$ & $6.92 \pm 1.15$ & 0.797 \\
\hline Lactose & $4.85 \pm 0.47$ & $5.04 \pm 0.42$ & 0.367 \\
\hline Protein & $5.19 \pm 0.39$ & $5.66 \pm 0.33$ & 0.012 \\
\hline Gross energy $(\mathrm{MJ} / \mathrm{kg})^{\#}$ & $4.73 \pm 0.22$ & $4.91 \pm 0.47$ & 0.297 \\
\hline \multicolumn{4}{|c|}{ Fatty acids (\% of total fatty acids) } \\
\hline 14:0 & $4.5 \pm 0.7$ & $4.6 \pm 0.6$ & 0.856 \\
\hline $16: 0$ & $27.1 \pm 1.6$ & $30.1 \pm 2.0$ & 0.006 \\
\hline $16: 1 n-9$ & $12.4 \pm 1.6$ & $12.1 \pm 1.0$ & 0.658 \\
\hline $18: 0$ & $2.9 \pm 0.4$ & $3.0 \pm 0.4$ & 0.360 \\
\hline $18: 1 \mathrm{n}-9$ & $31.7 \pm 3.5$ & $30.8 \pm 3.1$ & 0.570 \\
\hline $18: 1 \mathrm{n}-7$ & $1.9 \pm 0.3$ & $1.9 \pm 0.2$ & 0.819 \\
\hline $18: 2 n-6$ & $15.2 \pm 0.4$ & $13.7 \pm 0.7$ & $<0.001$ \\
\hline $18: 3 n-3$ & $1.2 \pm 0.1$ & $1.0 \pm 0.1$ & 0.018 \\
\hline$\Sigma$ SFA & $35.3 \pm 2.1$ & $38.5 \pm 2.7$ & 0.021 \\
\hline$\sum$ MUFA & $46.6 \pm 2.6$ & $45.3 \pm 2.6$ & 0.313 \\
\hline$\sum$ PUFA & $18.1 \pm 0.7$ & $16.3 \pm 0.9$ & $<0.001$ \\
\hline \multicolumn{4}{|c|}{ Fat soluble vitamins (nmol/g fat) } \\
\hline Retinol & $16.1 \pm 3.74$ & $17.9 \pm 4.46$ & 0.374 \\
\hline a-tocopherol & $83.4 \pm 27.1$ & $95.9 \pm 24.1$ & 0.314 \\
\hline
\end{tabular}

Values are mean \pm SD ( $n=10$ /group); Abbreviations: SFA saturated fatty acids, MUFA monounsaturated fatty acids, PUFA polyunsaturated fatty acids. ${ }^{\#}$ calculated value. 
linoleic acid, milk of sows administered clofibrate had a higher proportion of total saturated fatty acids and a lower proportion of total polyunsaturated fatty acids (PUFA) than milk of control sows (Table 5). The concentrations of the fat soluble vitamins retinol and $\alpha$ tocopherol in the milk, expressed per $g$ of fat, were also similar in both groups of sows (Table 5). Gains of litters during the first 14 days (the period in which piglets received sows milk exclusively) and the whole 21 days suckling period were also not different between control sows and sows supplemented with clofibrate (Table 6).

\section{Relative mRNA concentrations of components of the ubiquitin proteasome system in muscle}

In order to find out whether an enhanced proteolysis in muscle could be the reason for an increase of milk protein content found in sows treated with clofibrate, mRNA concentrations of $U B B$ (encoding ubiquitin), FBOX32 (encoding atrogin-1) and TRIM63 (encoding muscle specific RING Finger protein 1, MuRF-1) in muscle were determined. Relative mRNA concentrations of these three genes were higher in sows treated with clofibrate than in control sows [control group vs. clofibrate group: $U B B$, $1.00 \pm 0.23$ vs. $1.28 \pm 0.12(P=0.009) ; F B O X 32,1.00 \pm 0.64$ vs. $1.98 \pm 0.80(P=0.025)$; TRIM63, $1.00 \pm 0.45$ vs. $2.71 \pm$ $0.97(P=0.001)$; means \pm SD for all genes].

\section{Discussion}

This study was performed to investigate the effect of activation of PPAR $\alpha$ on the expression of genes involved in the utilization of fatty acids in liver and muscle of lactating sows. Moreover, we aimed to find out whether alterations in fatty acid utilization could affect milk fat synthesis. To induce activation of PPAR $\alpha$, lactating sows were fed a diet supplemented with clofibrate, a well-known synthetic agonist of PPAR $\alpha$ belonging to the group of fibrates [26]. We found that sows fed the diet supplemented with clofibrate indeed showed an up-regulation of several classical PPAR $\alpha$ target genes involved in fatty acid uptake and oxidation in liver and muscle which in its extent, however,

Table 6 Weights of litters from lactating control sows and sows administered clofibrate at birth and gains of litters during the period from day 1 to day 21 of lactation

\begin{tabular}{llll}
\hline & Control & Clofibrate & $P$-value \\
\hline Weights of litters $(\mathrm{kg})$ & & & \\
$\quad$ Day 1 & $12.5 \pm 1.28$ & $12.8 \pm 1.58$ & 0.657 \\
Day 21 & $57.4 \pm 6.09$ & $58.9 \pm 5.22$ & 0.602 \\
Gains of litters $(\mathrm{kg})$ & & & \\
Day 1 - day 14 & $28.0 \pm 4.09$ & $29.5 \pm 3.96$ & 0.448 \\
Day 1 - day 21 & $45.0 \pm 6.88$ & $46.1 \pm 5.25$ & 0.704 \\
\hline
\end{tabular}

Values are mean $\pm S D$ ( $n=10 /$ group). Litters were standardized to 8 piglets per sow. was weaker than in previous studies with young pigs treated with clofibrate $[15,27,28]$. The changes in mRNA concentrations of PPAR $\alpha$ target genes indicate that the clofibrate treatment of the sows caused a moderate activation of PPAR $\alpha$ in liver and muscle. The main reason for the relatively weak up-regulation of PPAR $\alpha$ target genes might be that the dose of clofibrate given to the sows in this study (2 $\mathrm{g} / \mathrm{kg}$ diet, equivalent to $45 \mathrm{mg} / \mathrm{kg}$ body weight) was lower than the doses given to young pigs in the recent studies $(5 \mathrm{~g} / \mathrm{kg}$ diet, equivalent to doses of 300$500 \mathrm{mg} / \mathrm{kg}$ body weight) $[15,27,28]$. Moreover, it should be noted that pigs have generally a relatively low expression of PPAR $\alpha$ in comparison to some other species such as rodents and target genes are less responsive against agonists $[15,27,29]$. It has been shown in sows that a negative energy balance commonly observed during lactation could induce activation of PPAR $\alpha$ due to increased concentrations of NEFA released from adipose tissue [16,17]. As the control sows considered in this study had only a slight negative energy balance which was reflected by low plasma NEFA concentrations, it is unlikely that there was a pronounced activation of PPAR $\alpha$ in tissues of the control sows. Moreover, it is unlikely that there was an activation of PPAR $\alpha$ by dietary fatty acids as the dietary fat, a mixture of soybean oil and palmoil (1:4, w/w), provided low amounts of highly unsaturated fatty acids with a high affinity to PPAR $\alpha$.

The finding that plasma TAG and NEFA concentrations were reduced by clofibrate treatment suggests that the moderate up-regulation of PPAR $\alpha$ target genes led to an increased utilization of TAG and fatty acids in tissues. Reduced plasma TAG concentrations which have been reported as a typical feature of activation of PPAR $\alpha$ in rats and pigs are mainly due to a reduced secretion of lipid from the liver into the blood and an increased clearance of plasma TAG by lipoprotein lipase (LPL) $[30,31]$. As sows treated with clofibrate showed an upregulation of LPL in muscle, it is likely that the reduction of plasma TAG concentration was at least in part due to an increased lipolysis. A reduction of plasma NEFA concentration which has also been reported in humans or animals treated with fibrates [32-35] might be mainly due to the up-regulation of fatty acid transporters which are direct targets of PPAR $\alpha$ [14]. In the present study, we observed an up-regulation of CD36, one of the key fatty acid transporters, in muscle of sows treated with clofibrate which might contribute to the reduction of plasma NEFA concentration observed in the sows treated with clofibrate.

The finding that fat and energy content of the milk and weight gains of litters during the suckling period (including the first 14 days of suckling in which sows milk was the only source of nutrients) were not different between the two groups of sows shows that the moderate 
up-regulation of PPAR $\alpha$ target genes in liver and muscle by clofibrate did not cause an impairment of milk synthesis in the mammary gland. Sows' milk fat consists mainly of two sources of fatty acids, namely those deriving from de-novo fatty acid synthesis in the mammary gland and those released from TAG-rich lipoproteins by LPL and taken up into the mammary gland. In contrast, plasma NEFA contribute less to the production of milk TAG as the uptake of NEFA into the mammary gland is relatively low in sows in comparison to other species such as cattle [36]. Fatty acids deriving from de-novo synthesis are mainly saturated and monounsaturated, while those transported via chylomicrons to the mammary gland are reflecting the dietary fatty acid profile [36]. A reduced plasma TAG concentration in sows treated with clofibrate indicates that there was a lower availability of fatty acids from TAG-rich lipoproteins in the mammary gland which might provide an explanation for the finding that milk of these sows had slightly lower concentrations of PUFA. Nevertheless, this study shows that a moderate reduction of plasma TAG concentration by administration of a strong PPAR $\alpha$ agonist does not impair milk fat synthesis.

An unexpected finding of this study was that sows treated with clofibrate showed an increased protein content in the milk. As milk protein synthesis depends on the availability of amino acids in the mammary gland [36], an increased flux of amino acids via blood to the mammary gland could provide a potential explanation for this observation. Recently, we have observed that treatment of rodents with clofibrate stimulates the ubiquitin proteasome system and enhances protein breakdown in muscle [37]. In the present study we observed that treatment of sows with clofibrate causes an upregulation of ubiquitin and the two E3 ligases atrogin-1 and MuRF-1 which are-rate limiting for the ubiquitin proteasome system. This finding suggests, although we do not have direct evidence for this, that treatment with clofibrate stimulates protein breakdown in muscle of sows which in turn could increase the availability of amino acids for milk protein synthesis. However, this remains a matter of speculation. We moreover observed that concentrations of retinol and $\alpha$-tocopherol in the milk were not different between the two groups indicating that clofibrate did not influence the metabolism of fat soluble vitamins, i.e. their delivery from TAG-rich lipoproteins into the mammary gland.

It has been established that dietary fatty acids such as n-3 PUFA can act as agonists of PPAR $\alpha$ [10-12]. Based on the fact that the PPAR $\alpha$ activating potential of those fatty acids is lower than that of synthetic PPAR $\alpha$ agonists such as clofibrate, the findings of the present study clearly indicate that fatty acids in sow diets acting as native PPAR $\alpha$ agonists might be uncritical with respect to milk production and gains of litters of lactating sows.
The study moreover suggests that a moderate upregulation of PPAR $\alpha$ target genes involved in fatty acid uptake and oxidation in liver and muscle as a consequence of a negative energy balance might not interfere with milk production of sows. This suggestion is supported by the observation that lactating sows are able to maintain their milk production even under the condition of a negative energy balance as long as their body fat reserves are not depleted to a large extent [38].

\section{Conclusions}

In overall, the present study shows that treatment of lactating sows with clofibrate, a strong synthetic PPAR $\alpha$ agonist, induces only a moderate activation of PPAR $\alpha$ in liver and muscle and in turn had limited effect on whole body fatty acid utilization. This may be the reason why clofibrate treatment did not influence milk composition and gains of litters during the suckling period. Thus, the present study indicates that activation of PPAR $\alpha$ induced either by native agonists such as dietary PUFA or a by negative energy balance might be largely uncritical in lactating sows with respect to milk production and litter gains in lactating sows.

\section{Competing interests}

The authors declare that they have no competing interests.

\section{Authors' contributions}

DKG conceived of the study, supervised the analyses and drafted the manuscript. BG performed the analyses and the statistical analyses. SR conducted the animal experiment. EM supervised the analysis of vitamins. SH and GR established and supervised the liver and muscle biopsy sampling procedure. SB conducted liver and muscle biopsy sampling. GE was responsible for animal keeping. KE conceived of the study, participated in its design and coordination and helped to draft the manuscript. All authors read and approved the final manuscript.

\section{Acknowledgements}

This study was supported by the German Research Foundation (Deutsche Forschungsgemeinschaft; Grant no. ED 70/9-1).

\section{Author details}

${ }^{1}$ Institute of Animal Nutrition and Nutritional Physiology, Justus-Liebig-University Giessen, Heinrich-Buff-Ring 26-32, 35392 Giessen, Germany. ²Department of Veterinary Clinical Sciences, Swine Diseases, Justus-Liebig-University, Frankfurter Straße 112, 35392 Giessen, Germany. ${ }^{3}$ Institute for Animal Breeding and Genetics, Justus-Liebig-University, Ludwigstraße 21b, 35390 Giessen, Germany.

Received: 26 March 2014 Accepted: 24 February 2015

Published online: 07 March 2015

\section{References}

1. Trayhurn P, Douglas JB, McGuckin MM. Brown adipose tissue thermogenesis is 'suppressed' during lactation in mice. Nature. 1982;298:59-60.

2. Dewey KG. Energy and protein requirements during lactation. Ann Rev Nutr. 1997;17:19-36.

3. Pedraza N, Solanes G, Iglesias R, Vázquez M, Giralt M, Villarroya F. Differential regulation of expression of genes encoding uncoupling proteins 2 and 3 in brown adipose tissue during lactation in mice. Biochem J. 2001;355:105-11.

4. Pedraza N, Solanes G, Carmona MC, Iglesias R, Viñas O, Mampel T, et al. Impaired expression of the uncoupling protein-3 gene in skeletal muscle during lactation: fibrates and troglitazone reverse lactation-induced downregulation of the uncoupling protein-3 gene. Diabetes. 2000;49:1224-30. 
5. Xiao XQ, Grove KL, Grayson BE, Smith MS. Inhibition of uncoupling protein expression during lactation: role of leptin. Endocrinology. 2004;145:830-8.

6. Xiao XQ, Grove KL, Smith MS. Metabolic adaptations in skeletal muscle during lactation: complementary deoxyribonucleic acid microarray and real-time polymerase chain reaction analysis of gene expression. Endocrinology. 2004;45:5344-54.

7. Gutgesell A, Ringseis R, Brandsch C, Stangl Gl, Hirche F, Eder K. Peroxisome proliferator-activated receptor alpha and enzymes of carnitine biosynthesis in the liver are down-regulated during lactation in rats. Metabolism. 2009;58:226-32.

8. Gutgesell A, Ringseis R, Schmidt E, Brandsch C, Stangl Gl, Eder K. Downregulation of peroxisome proliferator-activated receptor alpha and its coactivators in liver and skeletal muscle mediates the metabolic adaptations during lactation in mice. J Mol Endocrinol. 2009;43:241-50.

9. Ringseis R, Dathe C, Muschick A, Brandsch C, Eder K. Oxidized fat reduces milk triacylglycerol concentrations by inhibiting gene expression of lipoprotein lipase and fatty acid transporters in the mammary gland of rats. J Nutr. 2007;137:2056-61

10. Goto T, Kim Yl, Takahashi N, Kawada T. Natural compounds regulate energy metabolism by the modulating the activity of lipid-sensing nuclear receptors. Mol Nutr Food Res. 2013;57:20-33.

11. Xu HE, Lambert MH, Montana VG, Parks DJ, Blanchard SG, Brown PJ, et al. Molecular recognition of fatty acids by peroxisome proliferator-activated receptors. Mol Cell. 1999;3:397-403.

12. Jump DB. N-3 polyunsaturated fatty acid regulation of hepatic gene transcription. Curr Opin Lipidol. 2008;19:242-7.

13. Contreras AV, Torres N, Tovar AR. PPAR-a as a key nutritional and environmental sensor for metabolic adaptation. Adv Nutr. 2013;4:439-52.

14. Mandard S, Müller M, Kersten S. Peroxisome proliferator-activated receptor alpha target genes. Cell Mol Life Sci. 2004;61:393-416.

15. Cheon Y, Nara TY, Band MR, Beever JE, Wallig MA, Nakamura MT. Induction of overlapping genes by fasting and a peroxisome proliferator in pigs: evidence of functional PPAR alpha in nonproliferating species. Am J Physiol Regul Integr Comp Physiol. 2005;288:R1525-35.

16. Ringseis $R$, Heller $K$, Kluge $H$, Eder K. mRNA expression of genes involved in fatty acid utilization in skeletal muscle and white adipose tissues of sows during lactation. Comp Biochem Physiol A Mol Integr Physiol. 2011;158:450-4.

17. Rosenbaum S, Ringseis R, Hillen S, Becker S, Erhardt G, Reiner G, et al. Genomewide transcript profiling indicates induction of energy-generating pathways and an adaptive immune response in the liver of sows during lactation. Comp Biochem Physiol Part D Genomics Proteomics. 2012;7:370-81.

18. Rosenbaum S, Ringseis R, Most E, Hillen S, Becker S, Erhardt G, et al. Genes involved in carnitine synthesis and carnitine uptake are up-regulated in the liver of sows during lactation. Acta Vet Scand. 2013;55:24.

19. German Society for Nutrition Physiology (GfE). Empfehlungen zur Energie- und Nährstoffversorgung von Schweinen. Frankfurt am Main, Germany: DLG-Verlag; 2006.

20. Naumann K, Basler R, Seibold R, Barth C. Die chemische Untersuchung von Futtermitteln. In: Methodenbuch Bd. III. Darmstadt, Germany: VDLUFA Verlag; 1976

21. Hara A, Radin NS. Lipid extraction of tissues with a low toxicity solvent. Anal Biochem. 1978;90:420-6.

22. Schlegel G, Ringseis R, Shibani M, Most E, Schuster M, Schwarz FJ, et al. Influence of a rumen-protected conjugated linoleic acid mixture on carcass traits and meat quality in young Simmental heifers. J Anim Sci. 2012;90:1532-40

23. Balz MK, Schulte E, Thier HP. Simultaneous determination of tocopheryl acetate, tocopherols and tocotrienols by HPLC with fluorescence detection in foods. Fat Sci Technol. 1993;95:215-20.

24. Gessner DK, Schlegel G, Keller J, Schwarz FJ, Ringseis R, Eder K. Expression of target genes of nuclear factor E2-related factor 2 in the liver of dairy cows in the transition period and at different stages of lactation. J Dairy Sci. 2013;96:1038-43

25. Vandesompele J, De Preter K, Pattyn F, Poppe B, Van Roy N, De Paepe A, Speleman F. Accurate normalization of real-time quantitative RT-PCR data by geometric averaging of multiple internal control genes. Genome Biol. 2002;3:RESEARCH0034.

26. Willson TM, Wahli W. Peroxisome proliferator-activated receptor agonists. Curr Opin Chem Biol. 1997;1:235-41.
27. Luci S, Giemsa B, Kluge H, Eder K. Clofibrate causes an upregulation of PPARa target genes but does not alter expression of SREBP target genes in liver and adipose tissue of pigs. Am J Physiol Regul Integr Comp Physiol. 2007;293:R70-7.

28. Ringseis R, Luci S, Spielmann J, Kluge H, Fischer M, Geissler S, et al. Clofibrate treatment up-regulates novel organic cation transporter (OCTN)-2 in tissues of pigs as a model of non-proliferating species. Eur J Pharmacol. 2008:583:11-7.

29. Holden PR, Tugwood JD. Peroxisome proliferator-activated receptor a: role in rodent liver cancer and species differences. J Mol Endocrinol. 1999;22:1-8.

30. Auwerx J, Schoonjans K, Fruchart JC, Staels B. Transcriptional control of triglyceride metabolism: fibrates and fatty acids change the expression of the LPL and apo C-III genes by activating the nuclear receptor PPAR. Atherosclerosis. 1996;124(Suppl):S29-37.

31. Staels B, Schoonjans K, Fruchart JC, Auwerx J. The effects of fibrates and thiazolidinediones on plasma triglyceride metabolism are mediated by distinct peroxisome proliferator activated receptors (PPARs). Biochimie. 1997;79:95-9.

32. Catapano AL. Mode of action of fibrates. Pharmacol Res. 1992;26:331-40.

33. Bocos C, Herrera E. Comparative study on the in vivo and in vitro antilipolytic effects of etofibrate, nicotinic acid and clofibrate in the rat. Environ Toxicol Pharmacol. 1996;2:351-7.

34. Damci T, Tatliagac S, Osar Z, Ilkova H. Fenofibrate treatment is associated with better glycemic control and lower serum leptin and insulin levels in type 2 diabetic patients with hypertriglyceridemia. Eur J Intern Med. 2003;14:357-60.

35. Belfort R, Berria R, Cornell J, Cusi K. Fenofibrate reduces systemic inflammation markers independent of its effects on lipid and glucose metabolism in patients with the metabolic syndrome. J Clin Endocrinol Metab. 2010;95:829-36.

36. Boyd RD, Kensinger RS. Metabolic precursors for milk synthesis. In: Verstegen MWA, Moughan PJ, Schrama JW, editors. The lactating sow. Wageningen, The Netherlands: Wageningen Press; 1998. p. 71-97.

37. Ringseis R, Keller J, Lukas I, Spielmann J, Most E, Couturier A, et al. Treatment with pharmacological PPARa agonists stimulates the ubiquitin proteasome pathway and myofibrillar protein breakdown in skeletal muscle of rodents. Biochim Biophys Acta. 1830;2013:2105-17.

38. Noblet J, Etienne M, Dourmad J-Y. Energetic efficiency of milk production. In: Verstegen MWA, Moughan PJ, Schrama JW, editors. The lactating sow. Wageningen, The Netherlands: Wageningen Press; 1998. p. 113-30.

\section{Submit your next manuscript to BioMed Central and take full advantage of:}

- Convenient online submission

- Thorough peer review

- No space constraints or color figure charges

- Immediate publication on acceptance

- Inclusion in PubMed, CAS, Scopus and Google Scholar

- Research which is freely available for redistribution

Submit your manuscript at www.biomedcentral.com/submit 